\title{
CALLUS INDUCTION OF CACAO CLONE SULAWESI 1 ON VARIOUS CONCENTRATIONS OF 2,4 -D AND COCONUT WATER VIA IN VITRO CULTURE
}

\author{
Asmilal) $^{\text {I) Zainuddin Basri }}{ }^{2)}$, Ramal Yusuf $f^{2)}$ dan Hawalina ${ }^{2)}$ \\ Agrotechnology Program, Faculty of Agriculter, University of Tadulako, Palu, Email: asmila15@yahoo.com \\ Faculty of Agriculture, University of Tadulako, Palu, zainuddin.untad@gmail.com, \\ ryusufus@untad.ac.id,hawalinak@yahoo.com
}

\begin{abstract}
Cacao is one of important plantation crops grouped in the Sterculiaceae family. Sulawesi is the main area of cacao production and has a number of superior clones, such as Sulawesi 1 and Sulawesi 2. Based on data in 2012/2014 cacao production to consumption reached 174,000 tons, while in 2013/2014 was projected a deficit of 115,000 tonnes. Nonetheless, cacao agribusiness in Indonesia is still facing complex problems, among others gardener productivity is still low due to borer attacks cacao, the quality of products and the number is still low and still not optimal development of cacao products and providing superior amount of cacao seedlings. The primary problem of cacao production recently is low productivity. The main cause of low cacao productivity in Central Sulawesi is the use of inferior clones. To enhance cacao productivity, it is crucial to use cacao clones having high genetic potential via tissue culture or micropropagation techniques. The aim of this experiment was to assess the effect of different concentrations of 2,4-D and coconut water on the growth of cacao callus via in vitro culture. This experiment used Completely Randomozed Block Design in factorial patteren with treatments tested namely 2,4-D and coconut water concentrations. The concentrations of 2,4-D tested including $1 \mathrm{ppm}, 2 \mathrm{ppm}$ and $3 \mathrm{ppm}$, whilst coconut water concentrations tested consisting of $10 \%, 15 \%$ and $20 \%$, and therefore there were $3 \times 3=9$ treatment combinations. Each treatment utilized 4 replications; and each unit combination used 5 explants (staminodia). Results of this experiment indicated that the addition of $3 \mathrm{ppm} 2,4-\mathrm{D}$ and $10 \%$ coconut water had a highly significant effect on the callus color 4 weeks after culture. The addition of 3 ppm 2,4-D in culture media showed a significant effect on callus color 4 weeks after culture, but had an insignificant effect on the callus formation, callus color 8 weeks after culture an callus texture. Supplementation of $20 \%$ coconut water had a significant effect on callus texture 8 weeks after culture, whilst the addition of $10 \%$ coconut water showed a significant effect on callus color 4 weeks after culture.
\end{abstract}

Keywords: 2,4-D, Coconut water, Callus growth, Sulawesi 1 clone.

\section{INTRODUCTION}

The cocoa plant (Theobroma cacao L.) is an important plantation species which belongs to the Sterculiaceae family. Currently, Indonesia is one of the world's largest cocoa farmers and is among the third largest cocoa producing countries after Ivory Coast and Ghana (Wahyudi et al.,
2009). Based on data in 2012/2014 cocoa production to the consumption reached 174,000 tons, while in $2013 / 2014$ was projected to have deficit of 115,000 tons. The development to increase cocoa production in Indonesia has raised cacao plantation by both large estates and smallholders. While the production of processed products was estimated to grow 
up to 700 tons in 2015 from 268 thousand tons in 2011. The first step that must be performed in the development of cocoa cultivation to produce optimal production is by providing superior seeds and keeping the plants during the nursery because of the condition of the plant during the nursery greatly affects the growth of cocoa production. (BPS Indonesia, 2014).

Cocoa (Theobroma cacao L.) has many benefits, not only as a country's foreign exchange commodity but the cocoa bean is also the only main ingredient in making chocolate. In addition, cocoa is widely used as the main ingredient in some cosmetic products, pharmaceutical industry and so forth. Nevertheless, cocoa agribusiness in Indonesia still faces various complex problems including low productivity due to cocoa borer pest attack, low product quality and quantity as well as the non-optimal cocoa product development and provision of superior cocoa seedlings. This becomes a challenge to solve the problems faced by cocoa plantations as well as opportunities to grow the business and achieve greater added value from cocoa agribusiness (Silva et al., 2009; Argout et al, 2011; Veco, 2011).

The factors that cause low productivity of cocoa in Central Sulawesi namely pests and diseases, the application of cultivation technology is not optimal, some plants with old conditions and the use of species (clones) plants that have low production potential (Basri, 2010). Through tissue culture techniques or micropropagation is expected that these constraints can be overcome to obtain the plant material in large quantities with good quality and in a relatively short time.

Micropropagation through tissue culture can be performed in two ways: organogenesis and embryogenesis. Induction of callus is the beginning stage of embryogenesis indirectly. Callus is a collection of cells (mass of cells) that have not been differentiated by rapid cell division. The division of these cells is driven by growth regulators that added to the culture medium (Gunawan, 1992).

The common and effective growth regulator for cocoa callus induction is 2,4-D (2,4-Dichlorophenoxyacetic acid). The use of 2,4-D on tissue culture media has been widely reported. The results of the study of Avivi, et al. (2010) and Winarsih, et al. (2003) showed that the addition of 2,4-D in MS medium could stimulate callus formation from the cocoa flower staminodia explants.

In addition to 2,4-D, the addition of coconut water to culture media has been reported on cocoa plant callus induction. Coconut water contains a natural ZPT (hormone) that belongs to the cytokines group, namely 1,3 - diphenylurea, zeatin, zeatin glucoside, and zeatin riboside. In addition, coconut water also contains sucrose, fructose and glucose and contains high levels of $\mathrm{K}$ and $\mathrm{Cl}$ (Kristina and Syahidid, 2012).

To date, information on the use of tissue culture techniques in superior cocoa clones of Sulawesi especially that is related to the use of 2,4-D and the addition of coconut water to callus growth have not been reported so it is deemed necessary to undertake research on the growth of cocoa callus (Theobroma cacao L.) of Sulawesi 1 clone on 2.4-D concentrations and different coconut water via in vitro.

\section{RESEARCH METHODS}

Location and Time of Research. This research was conducted from September to December 2015 at the Plant Biotechnology Laboratory in Faculty of Agriculture, Tadulako University.

Tools and Materials. The tools used were autoclave, laminar air flow cabinet (LAFC), electric balance, oven, $\mathrm{pH}$ meter, water distiller, hot plate with magnetic stirrer, refrigerator, Bunsen burner, tweezers, scalpel, blade, measuring cup, beaker, hand sprayer, culture bottles, distilled water bottles, lab coats and stationery. 
The explant to be used was the cocoa flower staminodia from the still budged Sulawesi Clone 1. Other materials used were chemicals of MS composition (Murashige and Skoog), sucrose, phytagel, 2.4-D growth regulator, coconut water, $70 \%$ alcohol, sterile aquades, chlorox, detergents, methylated spirits, tissue, and paper labels.

Research Methods. The study was organized in a completely randomized design of the factorial pattern. The first factor, the concentration of 2,4-D consisted of 3 levels, namely: $1 \mathrm{ppm}, 2 \mathrm{ppm}$, and 3 $\mathrm{ppm}$ of 2,4-D. The second factor is the concentration of coconut water which consisted of three levels, namely: $10 \%$, $15 \%$, and $20 \%$, so there were $3 \times 3=9$ treatment combination. Each treatment was repeated 4 times, and each combination of treatment units consisted of 5 explants (staminodia).

The combination of the treatment as follows:

\begin{tabular}{|c|c|}
\hline \multicolumn{2}{|c|}{$\mathrm{D} 1 \mathrm{C} 1=1 \mathrm{ppm} 2,4-\mathrm{D}+10 \%$ coconut water } \\
\hline \multicolumn{2}{|c|}{$\mathrm{D} 1 \mathrm{C} 2=1 \mathrm{ppm} 2,4-\mathrm{D}+15 \%$ coconut wate } \\
\hline \multicolumn{2}{|c|}{$\mathrm{D} 1 \mathrm{C} 3=1 \mathrm{ppm} 2,4-\mathrm{D}+20 \%$ coconut wate } \\
\hline \multicolumn{2}{|c|}{$\mathrm{D} 2 \mathrm{C} 1=2 \mathrm{ppm} 2,4-\mathrm{D}+10 \%$ coconut wate } \\
\hline \multicolumn{2}{|c|}{$\mathrm{D} 2 \mathrm{C} 2=2 \mathrm{ppm} 2,4-\mathrm{D}+15 \%$ coconut wate } \\
\hline \multicolumn{2}{|c|}{$\mathrm{D} 2 \mathrm{C} 3=2 \mathrm{ppm} 2,4-\mathrm{D}+20 \%$ coconut wate } \\
\hline \multicolumn{2}{|c|}{$\mathrm{D} 3 \mathrm{C} 1=3 \mathrm{ppm} 2,4-\mathrm{D}+10 \%$ coconut wate } \\
\hline \multicolumn{2}{|c|}{$\mathrm{D} 3 \mathrm{C} 2=3 \mathrm{ppm} 2,4-\mathrm{D}+15 \%$ coconut wate } \\
\hline \multicolumn{2}{|c|}{$\mathrm{D} 3 \mathrm{C} 3=3 \mathrm{ppm} 2,4-\mathrm{D}+20 \%$ coconut water } \\
\hline Callus Color & Score \\
\hline White & 1 \\
\hline Yellowish White & 2 \\
\hline Yellow & 3 \\
\hline Brownish Yellow & 4 \\
\hline Brown & 5 \\
\hline Callus Texture & Score \\
\hline Friable & 1 \\
\hline Intermediates & 2 \\
\hline Compact & 3 \\
\hline
\end{tabular}

Observations included the appearance of callus and callus morphology. The callus morphology was performed by recording the callus characteristics, which include callus color (white, yellowish white, yellow, brownish yellow or brown) and callus structure that includes friable, medium or compact. Data on callus morphology were scored:

\section{RESULTS AND DISCUSSION}

\section{Results}

The Appearance of Callus. Analysis of variance showed that the treatment of coconut water (C) concentration was very significant while the 2.4-D (D) concentration treatment had no significant effect, nor was the interaction between the two treatments (Table 1).

DMRT test results showed that when the fastest callus appearance occurred in the treatment of coconut water of $20 \%$ and significantly different with the treatment of coconut water of $10 \%$ and $15 \%$.

Table 1. The average of Callus Appearance (Days After Planting).

\begin{tabular}{cc}
\hline Treatment & Callus Appearance (HST) \\
\hline $\mathrm{C} 1$ & $15.02^{\mathrm{a}}$ \\
\hline $\mathrm{C} 2$ & $15.83^{\mathrm{a}}$ \\
\hline $\mathrm{C} 3$ & $13.16^{\mathrm{b}}$ \\
\hline
\end{tabular}

Information : The number followed by the same alphabet has no significant difference at the DMRT level of 5\%.

Table 2. The average of Callus Appearance (4 Weeks After Planting).

\begin{tabular}{rccc}
\hline $2,4-\mathrm{D}$ & \multicolumn{3}{c}{ Coconut water (C) } \\
\cline { 2 - 4 }$(\mathrm{D})$ & $10 \%$ & $15 \%$ & $20 \%$ \\
\hline $1 \mathrm{ppm}$ & $\mathrm{p}^{3} 3.19^{\mathrm{a}}$ & $\mathrm{p} 3.25 \mathrm{a}$ & $\mathrm{p} 2.50^{\mathrm{b}}$ \\
\hline $2 \mathrm{ppm}$ & $\mathrm{p}^{3} 3.13^{\mathrm{a}}$ & $\mathrm{p} 3.19^{\mathrm{a}}$ & $\mathrm{p}^{2} 2.81^{\mathrm{a}}$ \\
\hline $3 \mathrm{ppm}$ & $\mathrm{q}^{2} 2.25^{\mathrm{b}}$ & $\mathrm{p} 3.06^{\mathrm{a}}$ & $\mathrm{p}^{3} 3.13^{\mathrm{a}}$ \\
\hline
\end{tabular}

Information : The numbers followed by the same letter on the same row $(a, b)$, and the same column ( $\mathrm{p}, \mathrm{q})$ which means has difference at the DMRT test level of $5 \%$. 
Callus Color on 4 WAP. The analysis of variance showed that the concentration of coconut water (C) had significant effect as well as the concentration of 2,4-D, while the interaction between the two treatments had a very significant effect on callus color on 4 WAP (Table 2).

The result of DMRT test of $5 \%$ showed that the best callus color was obtained on culture medium which added with $3 \mathrm{ppm}$ 2,4-D, that was the yellowish white (score 2.25). The color of callus on medium that added with $10 \%$ coconut water turned to brownish yellow (score> 3) when the concentration of $2,4-\mathrm{D}$ was reduced to 2 ppm until 1 ppm.

Media that was added with $3 \mathrm{ppm}$ 2.4-D showed the color of the callus also turned to brownish yellow (score> 3 ) when the coconut water concentration added to the medium increased from $10 \%$ of coconut water to $15 \%$ to $20 \%$ of coconut water. The callus color on the media that was added with $15 \%$ of coconut water, obtained brownish yellow callus for all 2,4-D concentrations trial (1 ppm - 3 ppm).

Good callus color on the media that was added with $20 \%$ of coconut water, was obtained with a concentration of $1 \mathrm{ppm} 2.4-$ $\mathrm{D}$ of yellowish white (score 2.50). Callus color turned to yellow (score 2.81) until brownish yellow (score 3.13) when the concentration of 2,4-D was increased to 2 until 3 ppm.

According to the results observed, the culture media that was added with 3 ppm 2.4-D and $10 \%$ coconut water was the best media concentration for callus formation that had the yellowish-white color of callus. (Table 2).

Callus Color on 8 WAP. The analysis of variance showed that the treatment of coconut water $(\mathrm{C})$ concentration was very significant while the concentration of 2,4-D (D) was not real, nor was the interaction between the two treatments (Table 3).

The results of DMRT test showed that the treatment of coconut water concentration of $20 \%$ gave the color of callus with a score of 3.06 which indicated the color of yellow callus (3) with brownish yellow (4) and significantly different with the $15 \%$ coconut water treatment gave callus of 3.73 scored which indicated the color of yellow callus (3) with brownish yellow (4), as well as with the treatment of coconut water concentration of $10 \%$ gave the color of callus with a score of 4.08 which indicated the color of brownish yellow callus (4) with brown (5) (Table 3 ).

Callus Texture. The analysis of variance showed that the coconut water concentration treatment was very significant while the 2.4-D concentration treatment had no significant effect, nor was the interaction between the two treatments (Table 4).

The results of DMRT test showed that the treatment of coconut water concentration of $20 \%$ gave callus texture with score 1.83 which indicated the texture between friable (1) with intermediate (2) and significantly different with $15 \%$ coconut water treatment that gave callus texture of 2.79 which indicated the texture between intermediate (2) and compact (3), as well as the treatment of $10 \%$ coconut water, gave a callus texture of 2.83 which indicated the texture between intermediates (2) and compact (3) on Table 4.

Table 3. The average of Callus Color (8 Weeks After Planting)

\begin{tabular}{cc}
\hline Treatment & Callus Color (WAP) \\
\hline $\mathrm{C} 1$ & $4.08^{\mathrm{a}}$ \\
\hline $\mathrm{C} 2$ & $3.73^{\mathrm{a}}$ \\
\hline $\mathrm{C} 3$ & $3.06^{\mathrm{b}}$ \\
\hline
\end{tabular}

Information : The number followed by the same alphabet has no significant difference at the DMRT level of $5 \%$.

Table 4. The average of Callus Texture on 8 Weeks After Planting (WAP)

\begin{tabular}{cc}
\hline Treatment & $\begin{array}{c}\text { The average of Callus } \\
\text { Texture } 8 \text { (WAP) }\end{array}$ \\
\hline $\mathrm{C} 1$ & $2.83^{\mathrm{a}}$ \\
\hline $\mathrm{C} 2$ & $2.79^{\mathrm{a}}$ \\
\hline $\mathrm{C} 3$ & $1.83^{\mathrm{b}}$ \\
\hline
\end{tabular}

Information : The number followed by the same alphabet has no significant difference at the DMRT level of $5 \%$. 


\section{Discussions.}

The addition of growth regulators in the tissue culture medium influences the cell growth rate of the cultured explant. The appearance of callus on the explant began from the former slices at the base of staminodia, and then spread throughout the staminodia. Before forming a callus, explant showed physical changes. At first, explant was shaped straight and then turned into crooked and enlarged and redder than the explant before cultured. Growth regulator on the growing medium would diffuse into the plant tissue through the base of the explants that were injured due to the incision. Coconut water and absorbed 2.4-D would stimulate the occurrence of cell division, especially cells that located at the base around the explant surface. The appearance of callus is characterized by the appearance of white cell clumps.

The fastest callus appearance was obtained on the treatment of $20 \%$ coconut water and significantly different with the treatment of $15 \%$ coconut water, as well as with the provision of $10 \%$ coconut water. Widiastoety (2008), stated that coconut water contains substances or ingredients such as carbohydrates, vitamins, minerals, proteins, and auxin, cytokines and gibberellins that stimulate tissue proliferation, metabolism, and respiration.

The addition of coconut water to callus initiation in the media is very influential in the appearance of callus (Nadar and Heins (1977), Seswita (2010)). In addition, according to Surachman (2011), the components contained in coconut water can interact with endogenous hormones possessed by each explant so as to stimulate cell division.

Based on the results obtained on the observation of callus color on 4 WAP, according to the observed results, the culture media that was added with 3 ppm 2.4-D and $10 \%$ coconut water is the best media concentration for callus formation that has the color of yellowish white callus. During the development of the callus in the growing media, the callus will experience physiological degradation or decreased physiological level of plants due to nutrient deficiency or growth hormone. In relation to the formation of embryogenic callus, Peterson \& Smith (1991) stated that the embryogenic callus is characterized by callus color which is yellowish white and shiny.

According to George (1993), if the auxin ratio is lower than cytokinin then organogenesis will lead to shoots, if auxin ratio is balanced with cytokinin it will lead to callus formation whereas if auxin is higher than cytokinin organogenesis will tend to lead to root formation.

The results obtained on the observation of callus color on 8 WAP, coconut water concentration of $20 \%$ gave the callus color between yellow and brownish yellow, while the concentration of $10 \%$ coconut water gave the callus color between brownish yellow and brown which showed symptoms of cell aging. Callus color describes the visual appearance of callus, so it can be known the level of activity of cell division (Rasud, 2012). George and Sherrington (1984) stated that the change in callus color is caused by the synthesis of phenolic substances in cells (callus).

Widayanto (2004) stated that the change in callus color from yellowish white to brown indicates a decrease in growth of callus cells. Such cells have very low division activity which result in reduced regeneration power. Based on the results obtained on the observation of callus texture on $8 \mathrm{WAP}$, the friable callus was produced on $20 \%$ coconut water concentration, and intermediate callus was produced on $15 \%$ coconut water concentration, while the compact callus was produced on $10 \%$ coconut water concentration. Based on the type of callus produced, friable callus is a callus that has good quality because it easily separated into single cells.

Callus type is a marker used to determine the quality of callus produced by 
explant (Rasud, 2012). (Turhan 2004) stated that visually, callus can be divided into three types namely compact, intermediates and friable. The good callus has a friable texture because it easily breaks into single cells.

According to Widyawati (2010), the formation of friable callus triggered by the presence of endogenous auxin hormone that is produced internally by the cultured explant. Furthermore, Widayanto (2004) stated that the friable callus is easily separated and if it is taken with tweezers, callus will break easily and some of its cells will stick to tweezers. On the contrary, compact callus has a texture that is difficult to separate and solid, the appearance of compact callus allegedly due to differences in the ability of plant tissue to absorb nutrients. According to Widyawati (2010), the formation of friable callus triggered by the presence of endogenous auxin hormone that is produced internally by the cultured explant. Furthermore, Widayanto (2004) stated that the friable callus is easily separated and if it is taken with tweezers, callus will break easily and some of its cells will stick to tweezers. On the contrary, compact callus has a texture that is difficult to separate and solid, the appearance of compact callus allegedly due to differences in the ability of plant tissue to absorb nutrients and growth regulators in the media. According to Widiarso (2010), intermediate callus is a callus mass which consists of a group of cells that are partially compact and some other are friable.

Based on the texture produced then the friable callus is characterized as an embryogenic callus. The embryogenic callus is usually characterized by a yellowish white, shiny and friable callus (easily separated and fragmented), while the non - embryogenic callus is brownish, somewhat pale and mushy so that it is difficult to separate. In this case, compact callus is indicated as non-embryogenic callus (non friable) (Peterson \& Smith, 1991).

\section{CONCLUSION AND SUGGESTION}

\section{Conclusion}

The culture media that was added with 3 ppm 2.4-D and $10 \%$ coconut water was the best media concentration for callus formation that had the yellowish-white color of callus.

The addition of 3 ppm 2,4-D is the best concentration in the formation of callus color on 4 WAP.

Addition of $20 \%$ coconut water is the best concentration for callus formation, callus color as well as callus texture.

\section{Suggestion}

In accordance with the results obtained, it can be suggested that for the growth of cocoa callus from staminodia, MS media can be added with $20 \%$ coconut water and 3 ppm 2,4-D.

\section{REFERENCES}

Argout, X., Jerome, S., Jean, M, A et al., 2011. The genome of Theobroma cacao. Articles, Volume 43, Number 2, February 2011, Nature Genetics.

Avivi. S., Prawoto. A., dan Oetami, F. R., 2010. Regenerasi Embriogenesis Somatik pada Beberapa KlonKakao Indonesia dari Eksplan Bunga. Fakultas Pertanian, Universitas Jember, Indonesian Coffeeand Cocoa Research Institute (ICCRI), Jember, Indonesia.

Basri, Z., 2004. Kultur Jaringan Tanaman. Universitas Tadulako Press, Palu.

BPS Indonesia., 2014, Sulawesi Tengah Dalam Angka. Kantor Pusat Statistik Provinsi Sulawesi Tengah,Palu. 
George, E.F dan Sherrington, P .D., 1993. Plant Propagation By Tissue Culture. Exegetis Ltd, England.

Gunawan, L,W., 1992. Teknik Kultur Jaringan Tanaman, Departemen Pendidikan Tinggi. Pusat Antar Universitas (PAU), Bioteknologi - IPB, Bogor.

Nadar, H. M., dan D.J. Heinz, 1997, Roots and Shoot Development From Sugarcane Callus Tissue. Crop Sci. 17:814-816.

Peterson, G., R. Smith. 1991. Effect of absicicic acid and callus size on regeneration of American and international rice varieties. Plants Cell Rep 10: 35-38.

Rasud Y., 2012. Induksi Kalus dan Inisiasi Tunas Cengkeh (Syzygium aromaticum L.) Secara In Vitro. Program Pasca Sarjana Universitas Tadulako. Palu.

Seswita, D., 2010. Penggunaan Coconut water Sebagai Zat Pengatur Tumbuh Pada Multiplikasi Tunas Temulawak (Curcuma xanthhorrhiza roxb.) in vitro. Jurnal littri 16 (4) Hlm. 135140.

Silva, T. E. R. T., Cidade, L, C., Alvim, F. C, Cascardo, J. C. M. , dan Costa, M,G, C., 2009. Studies On Genetic Transformation Of Theobroma cacao L. : And The Efficiency Of uidA Gene Transfer by Agrobacterium tumefaciens, Plant cell Tissue Organ Culture (2009) 99 : 287-298.

Suhendi, D., Winarno, H. Dan Susilo, A.W., 2004,Peningkatan Produksi dan Mutu Hasil Kakao Melalui Penggunaan Klon Unggul Baru. Prosiding Simposium Kakao 2004,Yogyakarta.

Surachman, D., 2011, Teknik Pemanfaatan coconut water untuk perbanyakan nilamsecara in vitro, Buletin Teknik Pertanian Vol. 16, No 1, 2011: 31-33.

Syahidid, S.F. dan Kristina, N.N.,2012, InduksidanRegenerasiKalusKeladiTikus (TyponiumflagelliformeLoodd.) SecaraIn Vitro, JurnalLittri Vol. 13. No 4: 142-146.

Turhan, H. 2004. Callus Inductions and Growth in Transgenic Potato Genotypes. Afrikan Journal of Biotechnology 3(8):375-378

Veco, 2011, Increased incomes for Indonesian cocoa farmers in sustainable markets: NGO-private sector cooperation on Sulawesi island. September 2011/veco-ngo.org.

Wahyudi, T., Panggabean, T. R., dan Pujianto., 2009, Panduan Lengkap Kakao,. Penebar Swadaya, Jakarta.

Widayanto, W. 2004. Pengaruh 2,4-D dan Kinetin Terhadap Pertumbuhan dan Perkembangan Eksplan Serta Kandungan Metabolit Sekender Kalus Jati Belanda (Guazuma ulmifolia Lamk.) Secara In Vitro. Fakultas Pertanian Universitas Sebelas Maret, Surakarta.

Widayanti, G. 2010. Pengaruh Varietas Konsentrasi NAA dan BAP terhadap Induksi dan Pertumbuhan Kalus Jarak Pagar (Jatropa Curcas L.,). Tesis Tidak Diterbitkan. Surakarta : Program Pasca Sarjana UNS.

Widiarso, M. 2010. Kajian Penggunaan BAP dan IBA untuk Merangsang Pembentukan Tunas Lengkeng (Dimocarpus Longan Lour) Varietas Pingpong Secara In Vitro. Skripsi Tidak Diterbitkan. Surakarta : Fakultas Pertanian UNS.

Widyawati, G., 2010. Pengaruh Variasi Konsntrasi NAA dan BAP Terhadap Induksi Kalus Jarak Pagar (JatrophacurcasL). Fakultas Pertanian, Universitas Sebelas Maret, Surakarta.

Winarsih, S., D. Santoso, T. Wardiyati. 2002. Embriogenesis somatik dan regenerasi dari eksplan embrio zigotik kakao (Theobroma cacao L.). Pelita Perkebunan 18:99-108. 